\title{
Candles from Soybean seed oil extract
}

\section{M.E. Ojewumi ${ }^{1 *}$, R.S. Bassey ${ }^{1}$, D.T. Oyekunle ${ }^{1}$}

${ }^{* 1}$, Chemical Engineering Department, Covenant University, P.M.B 1023, Canaan Land, Sango, Ogun State, Nigeria.

*11Corresponding author's e-mail: modupe.ojewumi@covenantuniversity.edu.ng

$1 *$ Orcid: 0000-0002-9254-2450

\begin{abstract}
This work is aimed at promoting a healthier means of livelihood by investigating insignificant areas of pollution. In this work, soy candles produced from soybeans were proven as healthier alternatives to paraffin candles. Soxhlet extraction method was used with hexane as solvent. The extracted oil were then solidified. The wax was moulded into candle and tests were carried out to prove its claims as a safer alternative to paraffin wax. The results supported this claims that soy candles is more economical and produced lesser soot than the paraffin candles.
\end{abstract}

Keywords: Soybeans, Soxhlet extraction, Oil extract, solvent, Yield

\section{INTRODUCTION}

Candle is mostly used for religious events and special occasion such as decorations during holidays. Traditional candles are mostly made of wax materials. Although, such candles emit trace of organic compounds when burned this include naphthalene, acrolein, formaldehyde and acetaldehyde [1,2]. Considerable amount of candles release lead which is a major source of concern in candle emissions for public health environments [3].

Different types of pollutants occur indoors under atmospheric conditions due to sources within or from the external environments. Most pollutants has negative consequences that are capable of causing various complications and nuisance [4-7]. Some pollutants can also be inform of solid waste materials which has to be removed either by physical or chemical means or by recycling by conversion into useful materials $[8,9,10,11]$. Mankind have continuously experience various forms of insomnia and psychological stress due to the stress experienced in present-day life (be it imagined or real) [12]. Therefore, numerous treatments have been proposed to supply psychological relief accompanying the healing process [3, 14-16]. Several treatments such as the application of scented candles has earned significant increase in the request for indoor air fresheners and room décor. The annual rapid growth in scented candles market in the U.S. is evaluated to be approximately 2 billion USD [3].

Although, some other sources have contributed to the amount of indoor air pollution. For example, pollutants such as odorants, polycyclic aromatic hydrocarbons (PAH) and metals are major components released from charcoals used during cooking process [16-21]. Combustion of these scented candles in an interior area result in the release of different aromatic constituents which can linger on within a building. The compounds identified include several alcohols, hydrocarbons and aldehydes. Also, various PAHs recognized as carcinogens such as pyrene, anthrancene and naphthalene were noted [21-25]. Besides, several other activities taking place 
indoors promote ultrafine and fine particulates emissions, igniting scented candles can stimulate emission of particulate matter and several other gaseous pollutants $[25,26]$. The amount of ultrafine density of particles from ignition of pure wax candles are up to about 241,000 particles $/ \mathrm{cm}^{3}$ [27]. Distinctive odour and enormous quantity of volatile organic compounds has been liberated from scented candles due to additives added such as aroma oil and fragrance [28]. Other pollution includes hydrocarbons which occurs as result of onsite or transportation spillage in the environment [29-32].

The process of combustion is mostly characterized by the presence of small sized particles, this has a negative effect on the wellbeing of living organisms due to its deposition in the alveolar, its inflammogenic potential, high reactivity on the surface and chemical decomposition [33]. Particulate matter usually contain PAHs which can generate development of large DNA mutations and adducts [34]. The occurrence of lung tissue damage and inflammation aggregate result to a considerable rise in proteins accumulation in the alveolar region. Moreover, production of excess oxygen reactive species by the immune cells or particles may result into oxidative destruction to biomolecules (e.g. DNA) [35]. Air pollution particles is related to oxidative stress, inflammation and high levels of oxidative DNA are destroyed in cultured cells, humans and animals $[35,36]$.

Studies such as Johnson [37] prepared candles by adding a binding agent to specific quantity of paraffin wax; the temperature of the paraffin wax and binding agent is increased, Soybean oil was added to the hot mixture of paraffin wax and binding agent; the mixture of paraffin wax, binding agent and soybean oil was increased to a very high temperature, where a specific quantity of candle scent was added to the hot mixture, dye was also added to the mixture; the mixture was added to water absorbing (wicked) containers for the manufacture of candles. Other studies by Baumer [38], Dieter Tischendorf [39], Jaeger [40], MacLaren [41] have also produced candles from various types of vegetable oils. This study considers the use steric acid on soy bean extract to produce wax, which are used for candle making. The product release less hazardous materials. Mathematical model which is regarded as a decision tool that assists decision makers in effectively dealing with complex issues can be used to optimise the extraction procedure to reduce the number of experimental run [28, 29, 42, 43, 44]. 


\section{Materials and Methods}

Source of raw materials: Raw soybean was obtained from an open market.

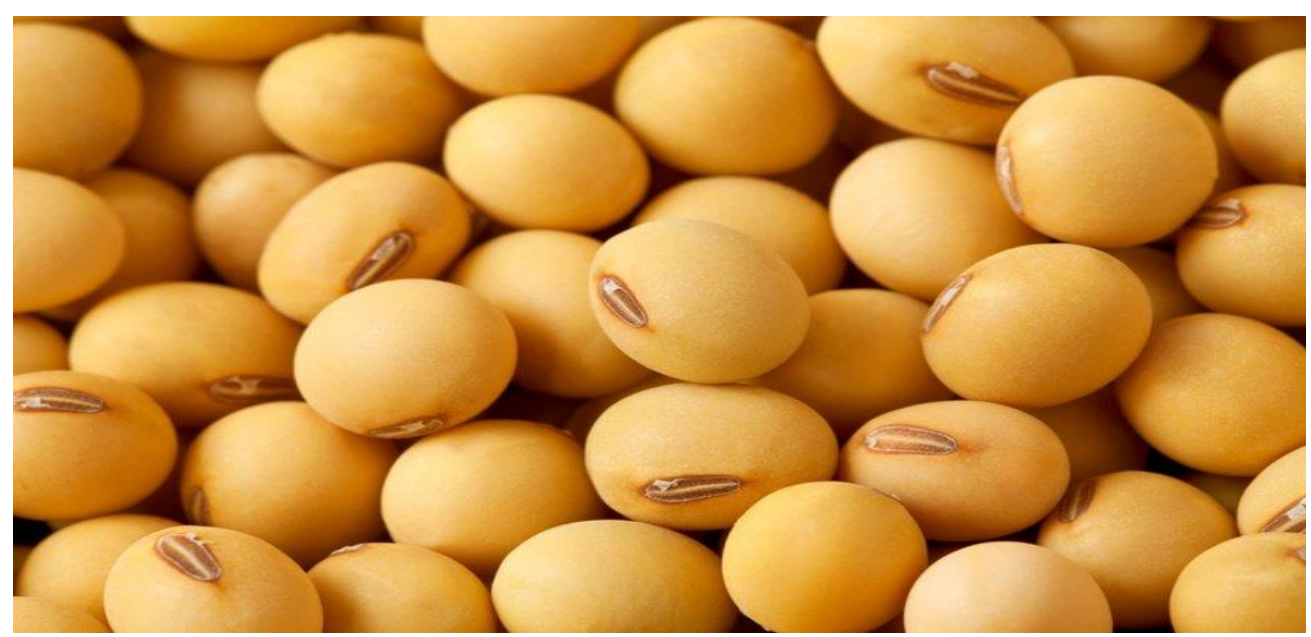

Figure 1: Picture of soybean

Preparation of Soybeans for extraction: Handpicked beans were washed in water and dehulled with palms to remove the cotyledon [45,46-50]. The washed and dehulled clean beans were oven dried at low temperature of $70^{\circ} \mathrm{C}$ for 48 days prior to extraction. The seeds were cracked in the mortar and pestle to weaken the binding power of the seeds and increase the surface area.

Extraction of Soybean oil using Hexane: Oil was extracted from the seeds using a Soxhlet extraction method. A condenser was placed on the extractor and properly connected to a water tap [41-42, 44-46]. The total yield of oil was expressed in percentage. Hexane used was recovered by a simple batch distillation process, using a reflux condenser [40, 41].

Solidification of the extracted Soybean oil with stearic acid: The crude oil extract was subjected to reaction with stearic acid to solidify it to wax. Other beautifying additives were incorporated into it after characterization such as fragrances and colour.

Comparison with a petroleum-based wax e.g. paraffin wax: The produced soy candle was compared with regular paraffin candle on certain physical parameters.

Physical Comparison: Both samples of same length were burned for a period of 20 minutes. At the end of 20 minutes, the samples were analysed on

a. Length left after burning (by observation)

b. Quantity of soot produced (by observation)

c. Colour of flame (by observation) 


\section{RESULTS AND DISCUSSION}

Determination of oil yield by varying extraction time, weight of sample and quantity of solvent.

The oil yield for the extraction of soybean oil with hexane for 2, 4, 6 and 8 hours is shown in the table below.

Table 1: Table for the extraction

\begin{tabular}{|c|c|c|c|c|c|c|c|}
\hline $\begin{array}{c}\text { StdO } \\
\text { rder }\end{array}$ & $\begin{array}{c}\text { Run } \\
\text { Order }\end{array}$ & $\begin{array}{c}\text { PtT } \\
\text { ype }\end{array}$ & $\begin{array}{c}\text { Blo } \\
\text { cks }\end{array}$ & $\begin{array}{c}\text { Weight of } \\
\text { seed }\left[\mathrm{X}_{1}\right]\end{array}$ & $\begin{array}{c}\text { Time of } \\
\text { Extraction } \\
{\left[\mathrm{X}_{2}\right]}\end{array}$ & $\begin{array}{c}\text { Quantity of } \\
\text { Solvent used } \\
{\left[\mathrm{X}_{3}\right]}\end{array}$ & $\begin{array}{c}\% \text { Oil yield } \\
{[\text { Response] }}\end{array}$ \\
\hline 7 & 1 & 2 & 1 & 10 & 6 & 160 & 12.67 \\
\hline 15 & 2 & 0 & 1 & 25 & 6 & 130 & 16.56 \\
\hline 3 & 3 & 2 & 1 & 10 & 10 & 130 & 14.55 \\
\hline 12 & 4 & 2 & 1 & 25 & 10 & 160 & 22.25 \\
\hline 6 & 5 & 2 & 1 & 40 & 6 & 100 & 18.5 \\
\hline 11 & 6 & 2 & 1 & 25 & 2 & 160 & 14.44 \\
\hline 8 & 7 & 2 & 1 & 40 & 6 & 160 & 18.5 \\
\hline 14 & 8 & 0 & 1 & 25 & 6 & 130 & 16.56 \\
\hline 1 & 9 & 2 & 1 & 10 & 2 & 130 & 10.59 \\
\hline 10 & 10 & 2 & 1 & 25 & 10 & 100 & 22.25 \\
\hline 4 & 11 & 2 & 1 & 40 & 10 & 130 & 24.24 \\
\hline 2 & 12 & 2 & 1 & 40 & 2 & 130 & 16.7 \\
\hline 9 & 13 & 2 & 1 & 25 & 2 & 100 & 14.44 \\
\hline 13 & 14 & 0 & 1 & 25 & 6 & 130 & 16.56 \\
\hline 5 & 15 & 2 & 1 & 10 & 6 & 100 & 12.66 \\
\hline
\end{tabular}

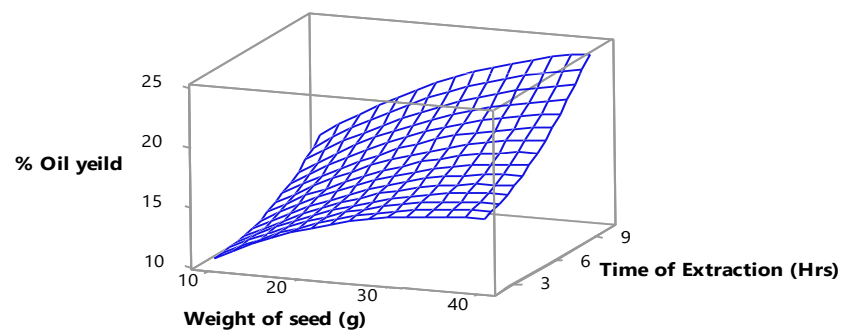

Figure 2: Surface Plot of \% Oil yield against Time of extraction (hrs) and Weight of seed (g) 


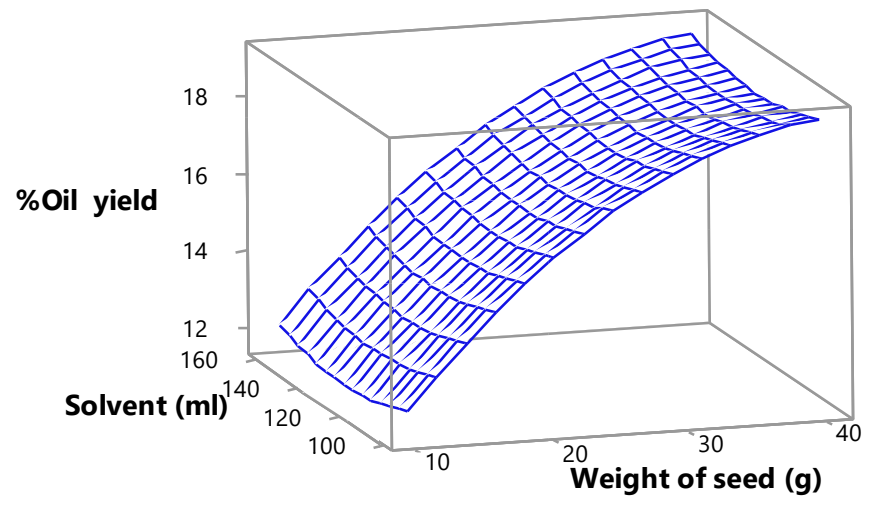

Figure 3: Surface Plot of Oil yield against Solvent (ml) and Weight of seed (g)

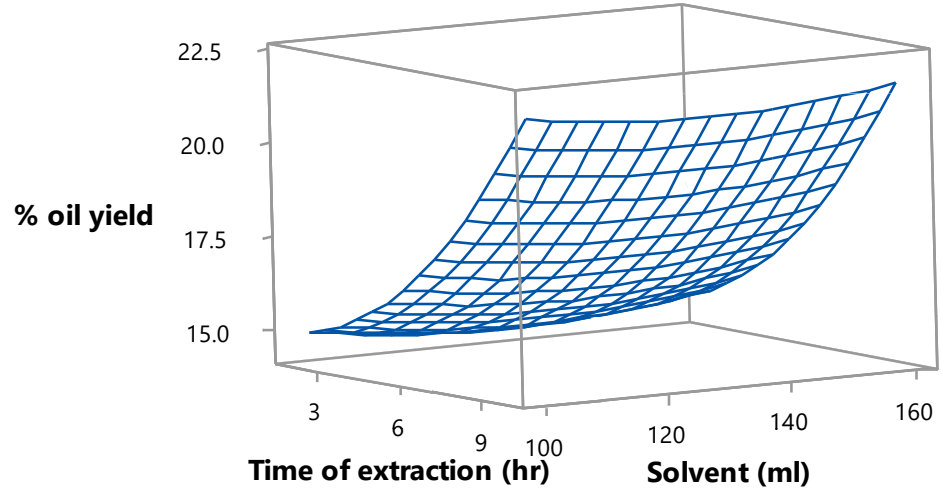

Figure 4: Surface plot of Oil yield against Solvent (ml), Time of extraction (hrs) 


\section{Results from physical Observation}

A sample of each candle was lit and observed. After a period of 5 minutes, the following observations were made.

Table 2. Results from Observation

\begin{tabular}{|l|l|l|}
\hline & Paraffin wax & Soy wax \\
\hline Colour of flame & Predominantly yellow & $\begin{array}{l}\text { An obvious combination of } \\
\text { blue and yellow }\end{array}$ \\
\hline Soot production & Noticeable & Negligible \\
\hline Length after 5 minutes & Obviously shorter & Slightly shorter \\
\hline
\end{tabular}

\section{Test for Gas Emissions}
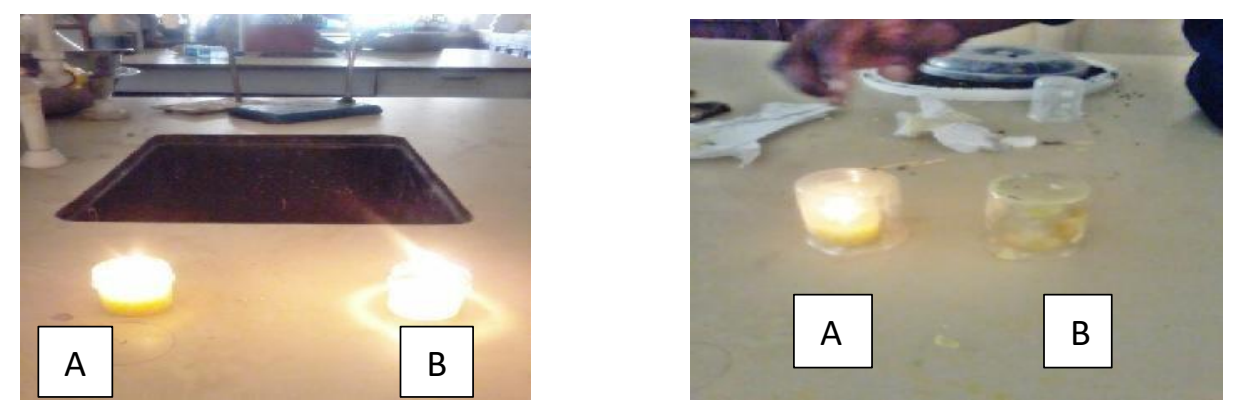

Figure A: Soybean candle

Figure B: Paraffin wax

\section{DISCUSSION OF RESULTS}

\section{The Effect of time on the \%yield of Oil:}

Soybean oil is about $30 \%$ of the total soybean content. The process of solvent extraction of this oil was carried out in the laboratory using hexane as a solvent and varying the extraction time. The extraction table (Table 1) shows more yield came from samples extracted for 10 hours with sample weight of 25 and $40 \mathrm{~g}$ which gave oil yield of 22.25 and $24.24 \%$ respectively. Solvent quantity had little or no effect on percentage oil yield during extraction process. 
Figures 2, 3 and 4 shows the surface plot relationship between the three variables considered (Weight of sample $\left[\mathrm{X}_{1}\right]$, time of extraction $\left[\mathrm{X}_{2}\right]$ and solvent quantity $\left[\mathrm{X}_{3}\right]$ ).

The simple mechanism of this extraction is that the oil dissolves readily in hexane solvent and is washed down from the powdered seeds by the flowing hexane. This explains the change in colour of hexane from a clear solution to yellow during the extraction process. More contact of the hexane with the seeds indicates dissolution of more oil from the seeds, thus the increase in oil yields at longer contact periods.

Conclusions: The yield of soybean oil depended on time of extraction, this was the major determinant of the oil yield in this research. From the flame colour observations, soy wax is considered a healthier alternative to the paraffin wax, hence soy candles are more eco-friendly than the paraffin candles in the sense that there are lesser or no toxic gases given off when burning soy candles. It is safe to burn paraffin candles in open space due to the rapid release of incombustible toxic gases. On the other hand, soy candles are preferable for lighting in enclosed space because they do not release much of toxic gases into the environment.

Conflict of interest: The authors declare no conflict of interest.

\section{References}

1. Lin K.-L., Method for Manufacturing a Candle, U.S. Patent, Editor. 1992.

2. $\quad$ Lau C., Fiedler, H., Hutzinger, O., Schwind, K.H., Hosseinpour, J., Levels of selected organic compounds in materials for candle production and human exposure to candle emissions. Chemosphere, 34(5-7): p. 1623-1630, 1997.

3. USEPA, Candles and incense as potential sources of indoor air pollution: market analysis and literature review. . Prepared by National Risk Management, Research Triangle Park, USEPA-600/R-01-001, 2001.

4. Brunekreef B., Holgate, S. T, Air pollution and health. Lancet, 360: p. 1233-1242, 2002.

5. Hammond C.J., Chemical composition of household malodours - an overview. Flavour Fragance J., 28: p. 251-261, 2013.

6. Bernstein J.A., Alexis, N., Barnes, C., Bernstein, I. L., Bernstein, J. A., Nel, A., Peden, D., Diaz-Sanchez, D., Tarlo, S.M., Williams, P.B.,, Health effects of air pollution. J. Allergy Clin. Immunol. , 114: p. 1116-1123, 2004.

7. Kampa M., Castanas, E.,, Human health effects of air pollution. Environ. Pollut., 151: p. 362-367, 2008.

8. Modupe E. Ojewumi, Oluwatobi E. Kolawole, Daniel T. Oyekunle, Olugbenga S. Taiwo, Alaba O. Adeyemi. Bioconversion of Waste Foolscap and Newspaper to Fermentable Sugar, Journal of Ecological Engineering, 20(4), 2019, 3541. https://doi.org/10.12911/22998993/102614

9. M. E. Ojewumi, M. E. Emetere, C. V. Amaefule, B. M. Durodola and O. D. Adeniyi (2019). Bioconversion of orange peel waste by escherichia coli and saccharomyces cerevisiae to ethanol, International Journal of Pharmaceutical Sciences and Research, Vol. 10(3): 1246-1252. DOI link: http://dx.doi.org/10.13040/IJPSR.0975-8232.10(3).1246-52.

10. Modupe Elizabeth Ojewumi, Akwayo Iniobong Job, Olugbenga Samson Taiwo, Oyinlola Mopelola Obanla, Ayodeji Ayodele Ayoola, Emmanuel Omotayo Ojewumi, Esther Adenike Oyeniyi (2018), Bio-conversion of Sweet Potato Peel Waste 
to Bio-ethanol Using Saccharomyces cerevisiae, International Journal of Pharmaceutical and Phytopharmacological Research (eIJPPR) 8(3); 46-54

11. Modupe Elizabeth Ojewumi, Barbra Ijeoma Obielue, Moses Eterigho Emetere, Olugbenga Olufemi Awolu, Emmanuel Omotayo Ojewumi (2018). Alkaline Pre-Treatment and Enzymatic Hydrolysis of Waste Papers to Fermentable Sugar. Journal of Ecological Engineering, 19(1), 211-217 https://doi.org/10.12911/22998993/79404।

12. Ahn J.H., Kim, K. H., Kim, Y. H., \& Kim, B. W., Characterization of hazardous and odorous volatiles emitted from scented candles before lighting and when lit. Journal of Hazardous Materials, 286: p. 242-251, 2015.

13. Wu J.J., Cui, Y., Yang, Y. S., Kang, M. S., Jung, S. C., Park, H. K., Yeun, H. Y., Jang, W. J., Lee, S., Kwak, Y. S., Eun, S. Y, Modulatory effects of aromatherapy massage intervention on electroencephalogram, psychological assessments, salivary cortisol and plasma brain-derived neurotrophic factor. Complementary Ther. Med., 22: p. 456462, 2014.

14. Hodge N.S., McCarthy, M. S., Pierce, R. M, A prospective randomized study of the effectiveness of aromatherapy for relief of postoperative nausea and vomiting. J. Perianesthesia Nursing: Official J. Am. Soc. PeriAnesthesia Nurses/Am. Soc. PeriAnesthesia Nurses, 29: p. 5-11, 2014.

15. Kim S., Kim, H. J., Yeo, J. S., Hong, S. J., Lee, J. M., Jeon, Y, The effect of lavender oil on stress, bispectral index values, and needle insertion pain in volunteers. J. Altern. Complementary Med., 17: p. 823-826, 2011.

16. Kabir E., Kim, K. H., Yoon, H. O, Trace metal contents in barbeque (BBQ) charcoal products. J. Hazard. Mater., 185: p. 1418-1424, 2011.

17. Kabir E., Kim, K. H., Ahn, J. W., Hong, O. F., Sohn, J. R, Barbecue charcoal combustion as a potential source of aromatic volatile organic compounds and carbonyls. J. Hazard. Mater., 174: p. 492-499., 2010.

18. Kim K.H., Pandey, S. K., Kabir, E., Susaya, J., Brown, R. J, The modern paradox of unregulated cooking activities and indoor air quality. J. Hazard. Mater., 195: p. 1-10, 2011.

19. Kim K.H., Jahan, S. A., Kabir, E, A review of diseases associated with household air pollution due to the use of biomass fuels. J. Hazard. Mater., 192: p. 425-431, 2011.

20. Susaya J., Kim, K.H., Ahn, J.W., Jung, M.C., Kang, C. H BBQ charcoal combustion as an important source of trace metal exposure to humans. J. Hazard. Mater., 176: p. 932937, 2010.

21. Derudi M., Gelosa ,S., Sliepcevich, A., Cattaneo, A., Rota, R., Cavallo, D., Nano, G Emissions of air pollutants from scented candles burning in a test chamber. Atmos. Environ., 55: p. 257-262, 2012.

22. Manoukian A., Quivet, E., Temime-Roussel, B., Nicolas, M., Maupetit, F., Wortham, $\mathrm{H}$ Emission characteristics of air pollutants from incense and candle burning in indoor atmospheres. Environ. Sci. Pollut. Res. Int., 20: p. 4659-4670, 2013.

23. Orecchio S., Polycyclic aromatic hydrocarbons (PAHs) in indoor emission from decorative candles. Atmos. Environ., 45: p. 1888-1895, 2011.

24. Petry T., Cazelle, E., Lloyd, P., Mascarenhas, R., Stijntjes, G, A standard method for measuring benzene and formaldehyde emissions from candles in emission test chambers for human health risk assessment purposes. Environ. Sci. Processes Impacts, 15: p. 1369-1382, 2013.

25. Petry T., Vitale, D., Joachim, F. J., Smith, B., Cruse, L., Mascarenhas, R., Schneider, S., Singal, M, Human health risk evaluation of selected VOC, SVOC and particulate emissions from scented candles. Regul. Toxicol. Pharm. RTP, 69: p. 55-70, 2014. 
26. Lee S., Wang, B, Characteristics of emissions of air pollutants from mosquito coils and candles burning in a large environmental chamber. Atmos. Environ., 40: p. 21282138, 2006.

27. Afshari A., Matson, U., Ekberg, L. E, Characterization of indoor sources of fine and ultrafine particles: a study conducted in a full-scale chamber. Indoor Air, 15: p. 141150, 2005.

28. Huang H.L., Tsai, T. J., Hsu, N. Y., Lee, C. C., Wu, P. C., Su, H. J, Effects of essential oils on the formation of formaldehyde and secondary organic aerosols in an aromatherapy environment. Build. Environ., 57: p. 120-125, 2012.

29. Ojewumi M.E., M.E. Emetere, D.E. Babatunde and J.O. Okeniyi, In Situ Bioremediation of Crude Petroleum Oil Polluted Soil Using Mathematical Experimentation. International Journal of Chemical Engineering, 2017, 2017.

30. Ojewumi M.E., J.O. Okeniyi, J.O. Ikotun, E.T. Okeniyi, V.A. Ejemen and A.P.I. Popoola, Bioremediation: Data on Pseudomonas aeruginosa effects on the bioremediation of crude oil polluted soil. Data in Brief, 19: p. 101-113, 2018.

31. Ojewumi M.E., J.O. Okeniyi, E.T. Okeniyi, J.O. Ikotun, V.A. Ejemen and E.T. Akinlabi, Bioremediation: Data on Biologically-Mediated Remediation of Crude Oil (Escravos Light) Polluted Soil using Aspergillus niger. Chemical Data Collections, 2018.

32. Ojewumi M.E., V.A. Ejemen, S.O. Taiwo, B.T. Adekeye, O.O. Awolu, E.O. Ojewumi. A Bioremediation Study of Raw and Treated Crude Petroleum Oil Polluted Soil with Aspergillus niger and Pseudomonas aeruginosa. Journal of Ecological Engineering, 19(2): p. 226-235, 2018.

33. Risom L., Møller, P., and Loft, S, Oxidative stress-induced DNA damage by particulate air pollution. Mutat. Res., 592: p. 119-137, 2005.

34. DeMarini D.M., Genotoxicity biomarkers associated with exposure to traffic and nearroad atmospheres: a review. Mutagenesis, 28: p. 485-505, 2013.

35. Skovmand A., Damiao Gouveia, A. C., Koponen, I. K., Møller, P., Loft, S., \& Roursgaard, M, Lung inflammation and genotoxicity in mice lungs after pulmonary exposure to candle light combustion particles. Toxicology Letters, 276: p. 31-38, 2017.

36. Møller P., Danielsen, P. H., Karottki, D. G., Jantzen, K., Roursgaard, M., Klingberg, H., Jensen, D. M., Christophersen, D. V., Hemmingsen, J. G., Cao, Y., and Loft, S, Oxidative stress and inflammation generated DNA damage by exposure to air pollution particles. Mutat. Res., 762: p. 133-166, 2014.

37. Johnson E.C., \& Johnson, C. L., Candle and the method of making the same, U.S. Patent, Editor. 2001.

38. Baumer N.J., \& Baltimore, M, Candles, U.S.P. Office, Editor. 1934.

39. Dieter Tischendorf, Method of producing candles consisting of vegetable or animal oils or fats, U.S.P. Application, Editor. 2005.

40. Jaeger A.O., Candle. 1934.

41. MacLaren F.H., Wax, U.S.P. Office, Editor. 1939.

42. Ojewumi M.E., K.G. Oyeyemi, M.E. Emetere and J.O. Okeniyi, Data on the rheological behavior of cassava starch paste using different models. Data in Brief, 19: p. 2163-2177, 2018.

43. Ojewumi M.E., J.A. Omoleye, A.A. Ajayi. Optimization of Fermentation Conditions for the Production of Protein Composition in Parkia biglobosa Seeds using Response Surface Methodology. International Journal of Applied Engineering Research, 12(22): p. 12852-12859, 2017.

44. Ojewumi M.E., S.O. Adedokun, A.A. Ayoola and O.S. Taiwo, Evaluation of the oil Extract from Mentha spicata and its Chemical Constituents. PONTE, 2018. 
45. Ojewumi M.E., Olizeke, Alternative solvent ratios for moringa oleifera seed oil extract. International Journal of Mechanical Engineering and Technology, 9(12): p. 295-307, 2018.

46. Ojewumi M.E., B. Eluagwule, A.A. Ayoola, A.T. Ogunbiyi, J. Adeoye, M.E. Emetere, and O.O. Joseph, Termiticidal effects of african locust bean (parkia biglobosa) seed oil extracts. International Journal of Current Research: p. 53929-53934, 2017.

47. Ojewumi M.E, Omoleye J.A, Ajayi A.A. Optimum Fermentation Temperature for the Protein Yield of Parkiabiglobosa Seeds (Iyere). Proceeding of the $3^{\text {rd }}$ International Conference on African Development Issues (CUICAD), 2016a; 584-587, Ota, Ogunstate, Nigeria. ISSN 2449-075X.

48. Ojewumi M.E, Omoleye J.A, Ajayi A.A. Optimization of Fermentation Conditions for the Production of Protein Composition in Parkia biglobosa Seeds using Response Surface Methodology. International Journal of Applied Engineering Research. 2017; 12(22):12852-12859.

49. Modupe Elizabeth Ojewumi, Abiodun James Omoleye, Atonye Stephanie Nyingifa (2018). Biological and chemical changes during the aerobic and anaerobic fermentation of African locust bean. International Journal of Chemistry Studies $2(2), 25-30$.

50. Modupe Elizabeth Ojewumi, Adebola Oyinade Odubiyi, James Abiodun Omoleye, Effect of Storage on Protein Composition of Fermented Soybean (Glycine Max) Seed by Bacillus Subtillis. Novel Techniques in Nutrition and Food Science [CRIMSON PUBLISHERS]. 2(4), 1-4. 